\title{
Anthropometric and physiological profiles of sepak takraw players
}

\author{
M N Jawis, R Singh, H J Singh, M N Yassin
}

Br J Sports Med 2005;39:825-829. doi: 10.1136/bjsm.2004.016915

See end of article for authors' affiliations

Correspondence to: Professor Rabindarjeet Singh, Universiti Sains Malaysia, Sports Science Unit, Kota Bharu Malaysia; rabindar@kb. usm.my

Accepted 3 April 2005
Objectives: Anthropometric and physiological profiles of national sepak takraw players were determined. Methods: Thirty nine players, specialising in the three playing positions (tekong/server, feeder, and killer/ spiker) were divided into three age categories of under 15 (U15), under 18 (U18), and under 23 (U23) years of age. Height, weight, percent body fat (\%bf), maximum oxygen consumption $\left(\mathrm{Vo}_{2 \max }\right)$, range of motion (ROM), back and leg strength, and heart rate, for the estimation of oxygen consumption during matches, were recorded. Statistical analysis was performed using one way ANOVA for independent measurements and data are presented as mean \pm standard deviation.

Results: The U23 players were significantly taller and heavier with significantly better ROM of the neck, trunk, and ankle joints and back and leg strength than the U15 players. No significant difference was found in \%bf between the three age categories. Mean maximum heart rate during exercise was significantly higher in the U15 group when compared to the U18 and U23 groups $(p<0.05)$. Mean $\mathrm{Vo}_{2 \text { max }}$ was similar between the three groups. Estimated oxygen consumption during matches was $69.1 \%$, $68.5 \%$, and $56.4 \%$ of $\mathrm{V}_{2 \max }$ in the killer, tekong, and the feeder groups, respectively.

Conclusions: The mean height, body weight, and cardiopulmonary capacities of the players were within the Malaysian population norms, but were somewhat lower than those of players of other court games from other countries. \%bf was also lower in these players. This study provides the much needed anthropometric and physiological data of sepak takraw players for further development of this sport.
$\mathrm{F}$

ollowing its introduction in the 10th Asian Games in Beijing in 1990, and as a demonstration sport in the 1998 Commonwealth Games in Kuala Lumpur, sepak takraw has become one of the fastest growing games in Asia and has spread to over 20 countries including Argentina, Australia, Brazil, Canada, Korea, Germany, England, India, Japan, Puerto Rico, Spain, and the USA. The game is played on an area the size of a doubles badminton court, with three players on each side of a $1.52 \mathrm{~m}$ high net (fig 1). A team consists of three players: feeder, tekong/server, and spiker/killer. ${ }^{1}$

Sepak takraw combines ball skills (kicking and juggling) with the agility and acrobatic moves of gymnasts and the instinctive reflexes of competitive badminton players (fig 2). As in volleyball, there are passes, sets, and spikes but all without the use of hands or arms. The players are allowed to use their head, chest, feet, and thighs to propel the ball over the net. Both setting and spiking is done with the feet and the two most commonly used spikes are the "sun back" spike (fig 3) and the "roll" spike (fig 4), which are performed aerially requiring immense agility, precision, leg strength, timing, and skill. Like badminton, squash, and tennis, the intensity of the game is intermittent, depending on the length of rallies following a serve.

Despite its increasing popularity, to date only one paper has been published on the physical and physiological profiles of sepak takraw players. ${ }^{1}$ However, player profiling has become a very important process on the road to excellence in sports. This study, therefore, presents some information on the physical and physiological profiles of the players at the National Sepak Takraw Grand Prix 2002 Championship; these are the top sepak takraw players in the country and some are in the national squad.

\section{METHODS}

\section{Subjects}

Thirty nine male, sepak takraw players on state and national teams, were divided into three age categories of under 15
(U15; $\mathrm{n}=12)$, under $18(\mathrm{U} 18 ; \mathrm{n}=15)$, and under 23 years (U23; $n=12$ ) of age. All subjects provided informed consent and the university's ethics committee approved the study. Anthropometric and cardiopulmonary parameters were then determined.

\section{Anthropometric measurements}

Height and weight were measured to the nearest $0.5 \mathrm{~cm}$ and $0.5 \mathrm{~kg}$, respectively, using a model 707 scale (Seca, Hamburg, Germany) with subjects standing bare foot and dressed in shorts or light clothing. Skin fold thickness was measured with a Harpenden calliper at four sites (abdomen, thigh, triceps, and suprailiac). ${ }^{2}$ The mean of three measurements represented the value for each site. Percent body fat (\%bf) was calculated using the four-site equation. ${ }^{3}$

\section{Back and leg strength}

Back and leg isometric strength was measured using a leg dynamometer (Takei Kiki Kogyo, Toyko, Japan). The subject stood on the platform with the trunk straight and the knees flexed to an angle of $130-140^{\circ}$. Holding the handle bar with a pronated grip, the subject pulled it slowly but vigorously, extending the knees and minimising the use of the lower back. Three attempts were allowed with a minimum of $60 \mathrm{~s}$ rest interval between them. The scores for all the three attempts were recorded with the best-pulled result taken as the measure of strength $(\mathrm{kg})$.

\section{Standing long jump}

Using a standing long jump mat, the subject jumped maximally with a countermovement jump prior to take off. The distance $(\mathrm{cm})$ from the takeoff line to the back of the heel closest to the takeoff line was recorded. ${ }^{4}$ A 2 min rest

Abbreviations: \%bf, percent body fat; $\mathrm{HR}_{\max }$, maximum heart rate; $\mathrm{O}_{2} \mathrm{P}_{\text {max }}$, maximum oxygen pulse; $\mathrm{ROM}$, range of motion; $\mathrm{SD}$, standard deviation; $V_{O_{2 m a x}}$ maximum oxygen consumption 


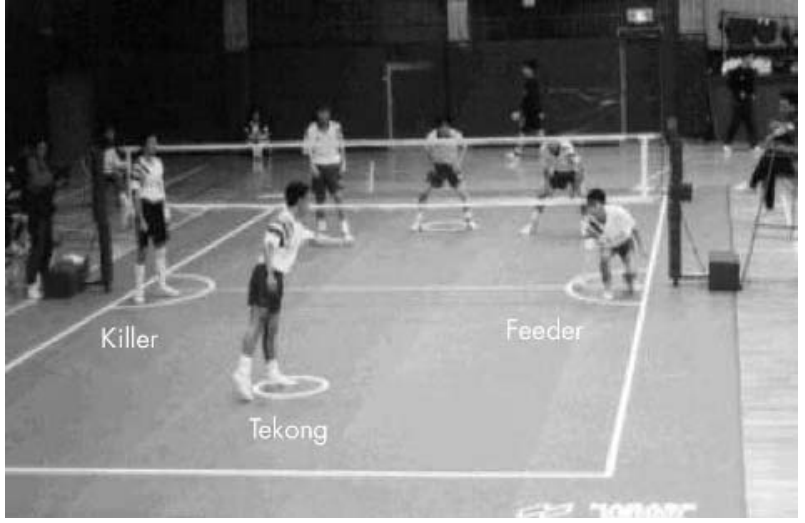

Figure 1 Positions in sepak takraw game before the start of a rally. (The players shown in this figure consented to the publication of this photograph.)

period was allowed between jumps to minimise the effect of fatigue. Standing long jump power was obtained by multiplying the distance jumped by body mass. The scores of all three jumps were recorded and best of the three jumps was taken as the measure of the jump.

\section{Range of motion}

The Leighton flexometer ${ }^{5}$ (Spokane, WA), a weighted $360^{\circ}$ goniometer, was used to assess static range of motion (ROM) of the right side of the neck, trunk, and ankle as described previously. ${ }^{7}$ The neck ROM (flexion and extension) was measured with the subject in a supine position with the head and neck projecting over the end of a bench, with the shoulders touching the edge of the bench and arms at the side. The flexometer was attached to the right side of the head and over the ear. The subject was first instructed to raise and flex the head forwards to a position as near to the chest and then to extend the head backwards as far as possible. These positions were held for $3 \mathrm{~s}$ each time and the angle was recorded to the nearest degree.

For the assessment of trunk ROM (rotation), the subject lay in a supine position on a bench with the knees together and raised above the hips with the legs held parallel to the bench and body. The flexometer was fastened around the middle of the thighs. With the shoulders held down, the subject was asked to move the knees sideways as far as possible, first to the left and then to the right. The ROM was recorded to the nearest degree.

The ROM of the ankle (flexion and extension) was obtained with the subject sitting on the bench with knees straight and the legs projecting over the end of the bench with the flexometer fastened to the inside of the right foot first. The subject was instructed to first extend the right foot downwards as far possible and then to flex the right foot upwards towards the knee as far as possible. The ROM was recorded to the nearest degree. For the inversion and eversion ROM of the ankle, the flexometer was fastened to the front of the shoe at the ankle. The subject sat at the end of the bench with the knees hanging over the bench. With lower legs secured in position by the assessor's free hand, the subject was asked to first to turn the foot inwards as far as possible and then to turn the foot outwards as far as possible. The ROM was then recorded to the nearest degree.

\section{Determination of maximum oxygen consumption $\left(V_{\mathbf{2}_{\text {max }}}\right)$}

Maximum oxygen uptake was determined using an incremental treadmill running test to exhaustion (Model 18-60, Quinton, Seattle, WA, USA) following prior familiarisation

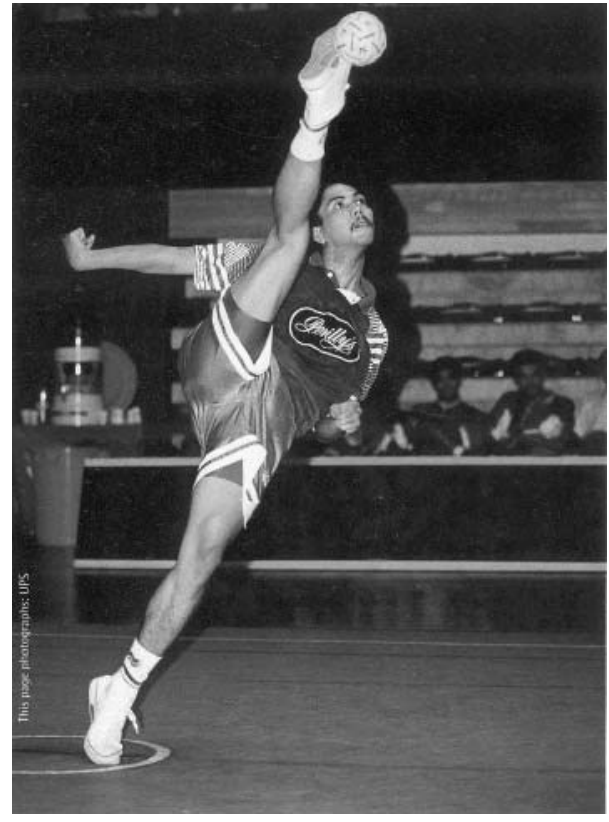

Figure 2 Execution of a sepak takraw service. (The player shown in this figure consented to the publication of this photograph.)

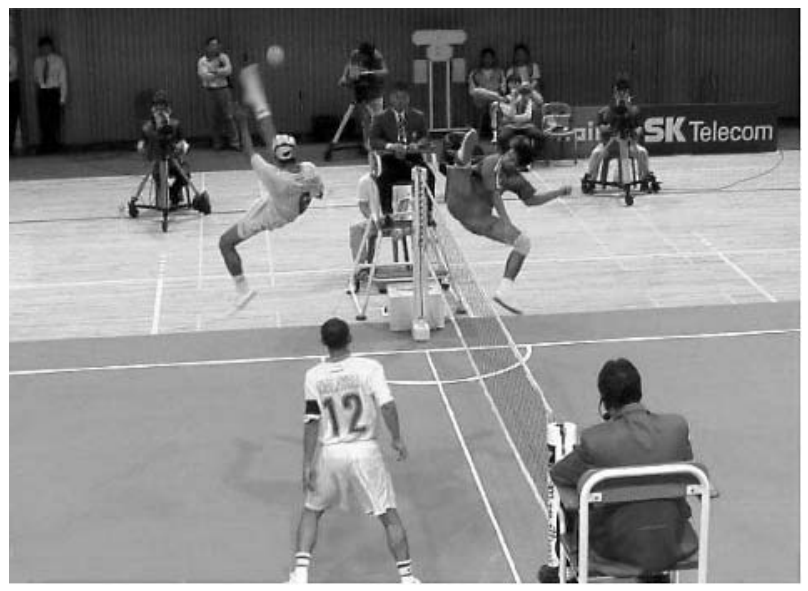

Figure 3 Execution of a sun back spike. (The players shown in this figure consented to the publication of this photograph.)

with the test procedures. Following a 5 min warm up, subjects ran at a predetermined speed for $\mathrm{Vo}_{2 \max }$ testing, which was maintained throughout the test. The gradient was increased by $2.5 \%$, from the initial $3.5 \%$ gradient, every 3 min until volitional exhaustion. ${ }^{8}$ Metabolic and respiratory measurements were carried out using a pre-calibrated metabolic chart recorder (SensorMedic 2900, Yorba Linda, CA, USA). Heart rates were recorded using a telemetry heart rate monitor (Polar, Kempele, Finland). Maximum oxygen pulse $\left(\mathrm{O}_{2} \mathrm{P}_{\max }\right)$ was determined by dividing maximum oxygen uptake in $\mathrm{ml} \mathrm{min}^{-1}$ with maximum heart rate obtained during the $\mathrm{Vo}_{2 \max }$ test.

\section{Determination of $\mathrm{Vo}_{2}$ during a match}

Oxygen consumption during a competitive game in an indoor stadium was estimated from the heart rates of players in each of the three positions (feeder, killer, and tekong) of a U23 team during four consecutive matches over a period of 


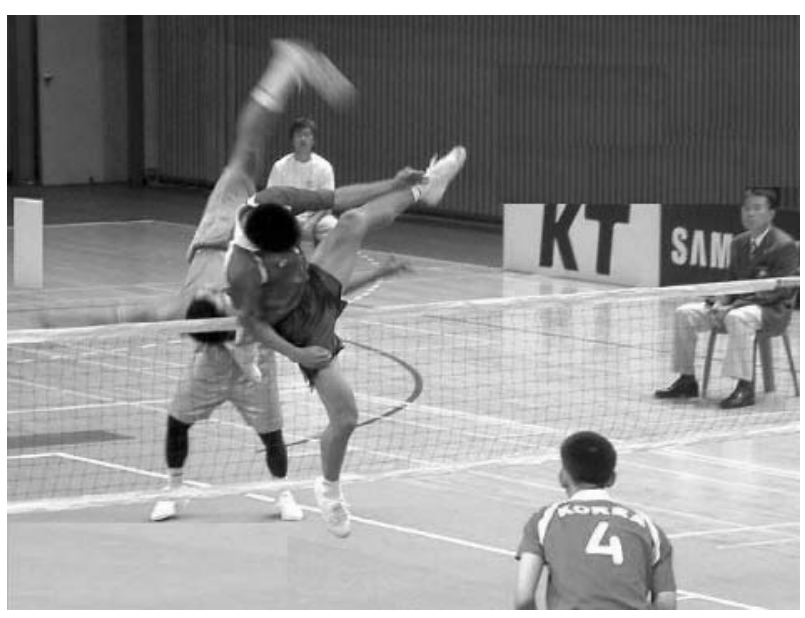

Figure 4 Positions of the spiker and the defender during execution of a role spike. (The players shown in this figure consented to the publication of this photograph.)

4 days, that is, each player's heart rate was recorded four times on 4 consecutive days. For this, each player was fitted with a heart rate transmitter and receiver (Polar) during the competitive game. Heart rates were recorded every minute in each individual during the game. After each game the data were downloaded onto a personal computer for analysis. Heart rates during each match were averaged and $\mathrm{Vo}_{2}$ was estimated from the respective heart rate versus oxygen consumption curves which were obtained in the laboratory a few days earlier as described by Bangsbo.. Duration of the matches (best of three sets of 21 points) varied between 45 and $70 \mathrm{~min}$.

\section{Statistical analysis}

One way analysis of variance (ANOVA) for independent measurements was used to compare the differences in all measured parameters. A Tukey post hoc test was used to locate the significant differences. A p $<0.05$ was considered to indicate statistical significance for all measurements. All data are presented as mean \pm standard deviation $(\mathrm{SD})$.

\section{RESULTS}

As expected, the U23 and U18 players were significantly taller than the U15 players $(p<0.001$; table 1$)$. Similarly, the U23 players were significantly heavier than the U15 players $(p<0.05)$. No significant differences were evident between the three groups as regards \%bf.

Mean neck and trunk ROMs of the U18 and U23 players were significantly greater than those of the U15 players $(\mathrm{p}<0.05$ and $\mathrm{p}<0.01$, respectively; table 2$)$. Mean ankle flexion/extension ROM of the U15 players was significantly

Table 1 Anthropometric measurements expressed as mean \pm SD for the three age categories

\begin{tabular}{|c|c|c|c|}
\hline \multirow[b]{2}{*}{ Variables } & \multicolumn{3}{|l|}{ Age categories } \\
\hline & U15 (n= 12) & U18 (n= 15) & U23 (n= 12) \\
\hline $\begin{array}{l}\text { Age (years) } \\
\text { Height }(\mathrm{m}) \\
\text { Weight }(\mathrm{kg}) \\
\text { Body fat }(\%)\end{array}$ & $\begin{array}{l}13.8 \pm 0.8^{* * *} \\
1.61 \pm 0.07^{* *} \\
49.7 \pm 7.3 \dagger \\
7.6 \pm 2.4\end{array}$ & $\begin{array}{l}16.7 \pm 1.0 \dagger \dagger \dagger \\
1.69 \pm 0.04 \\
58.7 \pm 10.3 \\
8.7 \pm 5.1\end{array}$ & $\begin{array}{l}20.4 \pm 1.3 \\
1.69 \pm 0.07 \\
61.9 \pm 10.6 \\
10.2 \pm 4.8\end{array}$ \\
\hline \multicolumn{4}{|c|}{$\begin{array}{l}\text { ** } p<0.01 \text {, }{ }^{* *} p<0.001 \text {, significantly different from the U18 and U23 } \\
\text { measurements, respectively. } \\
t p<0.05 \text {, }+\uparrow t p<0.001 \text {, significantly different from the U23 } \\
\text { measurement. }\end{array}$} \\
\hline
\end{tabular}

smaller than that of the U23 players $(\mathrm{p}<0.05)$. Mean ankle inversion/eversion ROM of the U18 players was significantly greater than that of the U15 players $(\mathrm{p}<0.05)$.

Back and leg strength of the U18 and U23 players was significantly higher than that of the U15 players $(p<0.05$ and $\mathrm{p}<0.001$, respectively; table 2 ). Leg strength was significantly greater in the U18 and U23 players when compared to that of the U15 players $(p<0.05$ and $p<0.01$, respectively). Similarly, mean leg power $\left(\mathrm{kg} \mathrm{m}^{-1}\right)$ in the U18 and U23 players was significantly greater than that in the U15 players $(p<0.05$ and $\mathrm{p}<0.001$, respectively).

Maximum heart rate $\left(\mathrm{HR}_{\max }\right)$ was significantly higher in the U15 players when compared to that of the U18 and U23 players $(\mathrm{p}<0.05$; table 2$)$. Absolute $\mathrm{Vo}_{2 \max }$ of the U18 and U23 players was significantly higher than that of the U15 players $(\mathrm{p}<0.01)$, whereas relative $\mathrm{Vo}_{2 \max }$ was similar in all three age categories. However, $\mathrm{O}_{2} \mathrm{P}_{\max }$ was significantly lower $(\mathrm{p}<0.001)$ in the U15 players than in the other two age groups.

No significant differences were evident between the mean heart rate of players in the three playing positions during the matches (table 3). However, oxygen consumption was somewhat lower in the feeder group compared to the tekong and the killer groups, but the difference was not statistically significant. When expressed as \% of $\mathrm{Vo}_{2 \max }$, average oxygen consumption ranged between $50 \%$ and $70 \%$ of the $\mathrm{Vo}_{2 \max }$ in players in the three playing positions.

\section{DISCUSSION}

Mean heights of the U23, U18, and U15 groups were found to be within the Malaysian population norms ${ }^{10}$ for their respective age categories. We do not have data from Malaysian players of other but similar court games and comparison is therefore difficult. But when compared to players of court games from other countries, it was found that the height of the Malaysian sepak takraw players was lower than that reported in Indian ${ }^{11}$ and Chinese badminton players ${ }^{12}$ and English squash players. ${ }^{13}$ The exact significance of height to performance in sepak takraw remains unclear, as there is no information in the literature correlating height with performance in this sport. While there may be a minimum height requirement in sepak takraw, it is unlikely that a greater than average height bestows any extra advantage to a player.

Having the correct body weight and body composition is important for athletes. Optimal body size and composition characteristics vary from sport to sport depending on the physical demands of the sport. ${ }^{14}$ The body weights of all the

Table 2 Range of motion (ROM) and strength characteristics (mean \pm SD) of the players in the three age categories

\begin{tabular}{|c|c|c|c|}
\hline \multirow[b]{2}{*}{ Variables } & \multicolumn{3}{|l|}{ Age categories } \\
\hline & U15 (n= 12) & U18 (n= 15) & U23 (n= 12) \\
\hline \multicolumn{4}{|c|}{ Neck ROM (deg) } \\
\hline Flexion/extension & $129.0 \pm 12.9$ & $142.1 \pm 12.3^{*}$ & $144.7 \pm 9.7^{* *}$ \\
\hline \\
\hline $\begin{array}{l}\text { Rotation } \\
\text { Ankle ROM (deg) }\end{array}$ & $125.1 \pm 17.1$ & $142.0 \pm 13.5^{\star *}$ & $142.4 \pm 20.2^{*}$ \\
\hline $\begin{array}{l}\text { Flexion/extension } \\
\text { Inversion/eversion }\end{array}$ & $\begin{array}{l}68.0 \pm 7.2 \\
58.7 \pm 8.7\end{array}$ & $\begin{array}{l}74.9 \pm 9.1 \\
66.9 \pm 4.2^{*}\end{array}$ & $\begin{array}{l}77.9 \pm 10.9^{*} \\
63.3 \pm 8.3\end{array}$ \\
\hline $\begin{array}{l}\text { Back and leg } \\
\text { strength }(\mathrm{kg})\end{array}$ & $108.8 \pm 18.8$ & $131.4 \pm 22.5^{*}$ & $149.0 \pm 23.5^{* * *}$ \\
\hline $\begin{array}{l}\text { Standing long } \\
\text { jump }(\mathrm{cm})\end{array}$ & $201.5 \pm 13.8$ & $217.9 \pm 17.8^{*}$ & $227.2 \pm 17.9^{* *}$ \\
\hline $\begin{array}{l}\text { Standing long } \\
\text { jump power }\left(\mathrm{kg} \mathrm{m}^{-1}\right)\end{array}$ & $100.2 \pm 16.6$ & $127.6 \pm 23.8^{*}$ & $140.6 \pm 26.6^{* * *}$ \\
\hline
\end{tabular}


Table 3 Heart rates, oxygen consumption, and \% $\mathrm{Vo}_{2 \text { max }}$ (mean $\pm \mathrm{SD}$ ) during matches in players in the three positions

\begin{tabular}{|c|c|c|c|}
\hline Players & $\begin{array}{l}\text { Heart rate } \\
\text { (beats } \min ^{-1} \text { ) }\end{array}$ & $\begin{array}{l}\mathrm{Vo}_{2}(\mathrm{ml} \\
\left.\mathrm{kg}^{-1} \min ^{-1}\right)\end{array}$ & $\% \mathrm{Vo}_{2 \max }$ \\
\hline $\begin{array}{l}\text { Feeder } \\
\text { Tekong/server } \\
\text { Killer/spiker }\end{array}$ & $\begin{array}{l}139.8 \pm 7.2 \\
142.9 \pm 6.3 \\
140.1 \pm 12.0\end{array}$ & $\begin{array}{l}29.8 \pm 2.8 \\
35.4 \pm 2.2 \\
36.7 \pm 5.4\end{array}$ & $\begin{array}{l}56.4 \pm 5.2 \\
68.5 \pm 4.2 \\
69.1 \pm 10.0\end{array}$ \\
\hline
\end{tabular}

sepak takraw players were within Malaysian population norms. ${ }^{10}$ When compared to body weights of players from other sports (in order to provide us with a picture of where sepak takraw players rank in terms of anthropometry and physiological capabilities), the mean weight of the U23 players was found to be lower than that of Italian ${ }^{15}$ and Indian $^{11}$ badminton players. The sepak takraw players also appear somewhat leaner and less muscular. The reason for these differences is uncertain but may reflect racial differences and the genetic make up of the individuals. Although mean \%bf increased with increasing age category, the differences were not statistically significant (table 1). The subjects who participated in the study were very lean with low \%bf (7.2-10\%) when compared to Malaysian dragon boat rowers whose average \%bf was $11.8 \%{ }^{16}$ The reason for the low \%bf is unclear. Under nutrition is no longer a problem in this part of the world. Whether the range of \%bf evident in this study is ideal for a sepak takraw player is uncertain, but it nevertheless seems that, as in numerous other court games, body fat of between 8 and $12 \%$ of body weight may be required for top level performance in sepak takraw. More studies are clearly needed to correlate \%bf with performance. Similarly, a height of 1.68-1.75 m, which was similar to that reported by Aziz et al, ${ }^{1}$ could also be considered an appropriate height for sepak takraw players. Nevertheless, more studies correlating body weight, height, and body composition to performance are required to confirm these assumptions.

Players in this study had an average to moderately high ROM based on norms set by Leighton ${ }^{5}$ (table 2). This may be an important attribute for excellence in sepak takraw, particularly flexibility of the lower limbs. The U23 players had better ROM in all joints measured. This may be due to the fact that they had been involved in the game for longer, whereas the U15 players performed only at school level and had less than a year's experience. ROM increases with long term stretching exercises or programmes. ${ }^{17-20}$ Although there may be a minimum ROM requirement of the trunk and ankle in sepak takraw, again there are no data correlating ROM with performance in other sports for comparison with sepak takraw.

The degree of explosive power of the sepak takraw players determined by performance in the standing long jump increased with increasing age category (table 2). The U23 players had leg power similar to that of age matched Malaysian dragon boat rowers. ${ }^{16}$ However, the explosive leg power performance of the sepak takraw players was lower compared to basketball players $\left(169.0 \mathrm{~kg} \mathrm{~m}^{-1}\right) .{ }^{21}$ Whether the explosive power of the U23 players, with an average height of $1.69 \mathrm{~m}$ and weight of $62 \mathrm{~kg}$, obtained in this study is ideal for sepak takraw is uncertain.

No statistically significant difference in $\mathrm{Vo}_{2 \max }$ was evident between the three groups (table 4). The aerobic capacities of these players were similar to those of Singaporean sepak takraw players ${ }^{1}$ but were somewhat lower than reported in Italian $\left(59.8 \mathrm{ml} \mathrm{kg}^{-1} \mathrm{~min}^{-1}\right)^{15}$ and Chinese badminton players $\left(63.4 \mathrm{ml} \mathrm{kg}^{-1} \mathrm{~min}^{-1}\right){ }^{12}$ They were also lower than
Table 4 Cardiopulmonary parameters (mean $\pm S D$ ) during maximum test for the three age categories

\begin{tabular}{|c|c|c|c|}
\hline \multirow[b]{2}{*}{ Variables } & \multicolumn{3}{|c|}{ Age categories } \\
\hline & U15 (n= 12) & U18 (n= 15) & U23 ( $n=12)$ \\
\hline$H R_{\max }$ (beats $\min ^{-1}$ ) & $195.9+8.7$ & $188.0+5.1^{*}$ & $187.7 \pm 7.2^{*}$ \\
\hline $\begin{array}{l}V_{o_{2 \max }}\left(\mathrm{ml} \mathrm{kg}^{-1}\right. \\
\left.\min ^{-1}\right)\end{array}$ & $51.9 \pm 3.9$ & $53.5 \pm 5.5$ & $51.2 \pm 4.5$ \\
\hline $\begin{array}{l}\mathrm{V}_{2 \max }\left(\left(\mathrm{min}^{-1}\right)\right. \\
\mathrm{O}_{2} \mathrm{P}_{\max }\left(\mathrm{ml} \mathrm{\text {beat } ^ { - 1 }}\right)\end{array}$ & $\begin{array}{r}2.5 \pm 0.3 \\
13.3 \pm 1.7\end{array}$ & $\begin{array}{c}3.1 \pm 0.5^{\text {** }} \\
16.9 \pm 2.5^{\text {*** }}\end{array}$ & $\begin{array}{c}3.2 \pm 0.5^{* *} \\
17.2 \pm 2.2^{* \star *}\end{array}$ \\
\hline
\end{tabular}

${ }^{*} \mathrm{p}<0.05,{ }^{* *} \mathrm{p}<0.01,{ }^{* * *} \mathrm{p}<0.001$ significantly different from U15. $\mathrm{HR}_{\text {max }}$, maximum heart rate; $\mathrm{O}_{2} \mathrm{P}_{\text {max }}$, maximum oxygen pulse; $\mathrm{V}_{2 \text { max }}$ maximum oxygen consumption.

those observed in English junior squash $\left(57.2 \mathrm{ml} \mathrm{kg}^{-1}\right.$ $\left.\min ^{-1}\right),{ }^{13}$ and university division tennis $\left(58.5 \mathrm{ml} \mathrm{kg}^{-1}\right.$ $\left.\min ^{-1}\right)^{22}$ players. The reason for this is not immediately apparent but may be related to training and the requirements of the game. As sepak takraw is a game of lower work intensity compared to badminton, squash, tennis, and even basketball, it is therefore not surprising that sepak takraw players have a lower aerobic capacity as also reported by Aziz et al. ${ }^{1}$

Estimation of $\mathrm{VO}_{2}$ from heart rates during competitive matches revealed workload intensities of about $70 \%$ of maximum heart rates or between 50 and $72 \%$ of $\mathrm{Vo}_{2 \max }$ (table 3 ). The $70 \%$ maximum heart rate recorded during the matches was slightly lower than that reported by Aziz et al. ${ }^{1}$ The reason for this is unclear, but it may be related to the environment as their games were held outdoors whereas the matches in this study were held in an air conditioned indoor stadium. Oxygen consumption ranged between 28 and $43 \mathrm{ml}$ $\mathrm{kg}^{-1} \min ^{-1}$ during competitive matches. Although mean $\mathrm{Vo}_{2}$ was lower in the feeder group, there was no significant difference between the players in the three playing positions. This may be due to the small number of subjects per group. These values are lower than those reported for badminton ${ }^{12} 15$ players, where oxygen consumption rates of between 45 and $52 \mathrm{ml} \mathrm{kg} \mathrm{min}^{-1}$ or between 75 and $86 \%$ of $\mathrm{Vo}_{2 \max }$ have been observed. The difference in the oxygen consumption during the game and the lower $\mathrm{Vo}_{2 \max }$ of the sepak takraw players confirms the lower work intensity of this sport.

In conclusion, these data appear to be the first of their kind obtained from sepak takraw players in Malaysia and provide a useful database against which talented groups may be compared for talent detection, identification, and development programmes.

\section{ACKNOWLEDGEMENTS}

The authors would like to thank all the players for their invaluable participation and cooperation. The authors also wish to thank Willy Pieter for statistical advice.

\section{Authors' affiliations}

M N Jawis, R Singh, H J Singh, M N Yassin, Universiti Sains Malaysia, Kota Bharu, Malaysia

This study was supported by a short term research grant from Universiti Sains Malaysia (304/PPSP/6131229)

Competing interests: none declared

The players described in this article consented to the publication of their details and photographs

\section{REFERENCES}

1 Aziz AR, Teo Eikman, Tan B, et al. Sepaktakraw: a descriptive analysis of heart rate and blood lactate response and physiological profile of elite players. Int J Appl Sports Sci 2000;15:1-10.

2 American College of Sports Medicine. Guidelines for exercise testing and prescription, 5th ed. Baltimore: Williams and Wilkins, 1995. 


\section{What is already known on this topic}

Except for one report which analyses the temporal characteristics of sepak takraw, there are no other published data on a sport which is increasing in popularity.

3 Forsyth HL, Sinning WE. The anthropometric estimation of body density and lean body weight of male athletes. Med Sci Sports 1973;5:174-80.

4 Robertson DG, Fleming D. Kinetics of standing broad and vertical jumping. Can J Sport Sci, 1987;12;19-23.

5 Leighton JR. An instrument and technique for measurement of range of joint motion. Arch Phys Med Rehabil 1987;36:571-8.

6 Leighton JR. The Leighton flexometer and flexibility test. J Assoc Phys Ment Rehabil 1966;20:86-93.

7 Leighton JR, Holmes D, Benson J, et al. A study on the effectiveness of ten different methods of progressive resistance exercise on the development of strength, flexibility, girth and body weight. J Assoc Phys Ment Rehabil 1967;21:78-81.

8 Taylor HL, Buskirk E, Henschel A. Maximum oxygen intake as an objective measure of cardiorespiratory performance. J Appl Physiol 1955;8:73-80.

9 Bangsbo J. The physiology of soccer - with special reference to intense intermittent exercise. Acta Physiol Scand Suppl 1994:619:1-155.

10 Singh R, Singh HJ, Sirisinghe RG. Cardiopulmonary fitness in a sample of Malaysian population. Jap J Physiol 1989;39:475-85.

11 Majumdar P, Khanna GL, Malik V, et al. Physiological analysis to quantify training load in badminton. Br J Sports Med 1997;31:342-5.

12 Chin MK, Wong AS, So RC, et al. Sports specific fitness testing of elite badminton players. Br J Sports Med 1995;29:153-7.

13 Brown D, Weigand DA, Winter EM. Maximum oxygen uptake in junior and senior elite squash players. In: Lees A, Maynard I, Hughes M, eds, et al. Science and racquets sports. Vol 2. London: E\&FN Spon, 1998:14-9.

14 Boileau RA, Horswill CA. Body composition in sports: measurement and application for weight loss and gain. In: Garret WE, Kirkendall DT, eds. Exercise and sports science. Philadelphia: Lippincott, Williams and Wilkins, 2000:319-38.

15 Faccini P, Dai Monte A. Physiologic demand of badminton match play. Am J Sports Med 1996;24:S64-6.

16 Singh R, Singh HJ, Sirisinghe RG. Physical and physiological profiles of Malaysian dragon boat rowers. Br J Sports Med 1995;29:13-5.

17 De Vries HA. Flexibility. In: Physiology of exercise for physical education and athletics. Dubuque, IA: WC Brown, 1986:462-72.
What this study adds

This study provides much needed anthropometric and physiological information for the future development of sepak takraw.

18 Stone MH, Fleck SJ, Triplett NT, et al. Health- and performance-related potential of resistance training. Sports Med 1991;11:210-31.

19 Etnyre BR, Lee EJ. Chronic and acute flexibility of men and women using three different stretching techniques. Res Q Exerc Sport 1989;59:222-8.

20 Sady SP, Wortman M, Blanke D. Flexibility training: ballistic, static or proprioceptive neuromuscular facilitation? Arch Phys Med Rehabil 1982:63:261-3.

21 Hoffman JR, Maresh CM. Physiology of basketball. In: Garret WE, Kirkendall DT, eds. Exercise and sports science. Philadelphia: Lippincott, Williams and Wilkins, 2000:733-44.

22 Bergeron MF, Maresh CM, Kraemer WJ, et al. Tennis: a physiological profile during match play. Int J Sports Med 1991;12:474-9.

\section{COMMENTARY}

The paper will prove useful in providing coaches and trainers with information on the physical and physiological demands of sepak tekraw, a sport suitable for the average Asian since the height requirement is $164-175 \mathrm{~cm}$. The metabolic and cardiorespiratory demands of the sport are moderate and great motor ability and strength are not required, but players need to be very flexible and agile. The players should receive optimal cardiorespiratory fitness and strength training to minimise the chances of injury.

G L Khanna Sports Authority of India, New Delhi, India; glkhanna56@hotmail.com 